\title{
A small omnivore fish (Acheilognathus macropterus) reduces both growth and biomass of submerged macrophytes: implications for shallow lake restoration
}

\author{
Jinlei $\mathrm{Yu}^{1, *}$, Manli Xia ${ }^{1,2}$, Wei Zhen ${ }^{3}, \mathrm{Hu} \mathrm{He}^{1}$, Ruijie Shen ${ }^{1}$, Baohua Guan ${ }^{1,4}$ and Zhengwen Liu ${ }^{1,2,4}$ \\ ${ }^{1}$ State Key Laboratory of Lake Science and Environment, Nanjing Institute of Geography and Limnology, Chinese Academy of \\ Sciences, Nanjing 210008, China \\ ${ }^{2}$ Department of Ecology and Institute of Hydrobiology, Jinan University, Guangzhou 510630, China \\ 3 Wuhan Zhiyue Water Ecological Technology Limited Company, Wuhan 430014, China \\ ${ }^{4}$ Sino-Danish Centre for Education and Research (SDC), University of Chinese Academy of Sciences, Beijing 100190, China
}

Received: 16 April 2020 / Accepted: 1 July 2020

\begin{abstract}
Transplantation of submerged macrophytes has been widely used to improve water quality in restoring shallow lakes in China. However, in some lakes, small omnivorous fish predominated the fish assemblages and fed mainly on submerged macrophytes. Despite significant research examining grazing selectivity in herbivorous fishes, macrophyte feeding preferences of small omnivorous fishes are poorly understood. We conducted a mesocosm experiment to examine the effects of a prolific small omnivorous bitterling fish Acheilognathus macropterus on the relative growth rate (RGR) and biomass of submerged macrophytes (Ceratophyllum demersum, Myriophyllum spicatum, Vallisneria denseserrulata, and Hydrilla verticillata). Our results showed that the presence of $A$. macropterus significantly increased nutrient concentrations (e.g. total nitrogen and total phosphorus). The RGR of $C$. demersum in the bitterling-present treatment was significantly lower than the controls, in the presence of other macrophyte species. Further, total biomass of the four species of macrophytes in the fish-present mesocosms was markedly lower than in the fish-absent treatment, suggesting considerable consumption of macrophytes by bitterling. Moreover, the percent biomass of $V$. denserrulata and $H$. verticillata were significantly enhanced by the presence of bitterling. Our findings suggest that $A$. macropterus may increase nutrient concentrations through excretion and reduce the biomass and RGR of certain submerged macrophytes which may shift macrophyte community structure via selective grazing.
\end{abstract}

Keywords: Omnivore / Ceratophyllum / bitterling / feeding preference / herbivory

Résumé - Un petit poisson omnivore (Acheilognathus macropterus) réduit à la fois la croissance et la biomasse des macrophytes submergés : implications pour la restauration des lacs peu profonds. La transplantation de macrophytes submergés a été largement utilisée pour améliorer la qualité de l'eau dans la restauration des lacs peu profonds en Chine. Cependant, dans certains lacs, les petits poissons omnivores ont dominé les communautés de poissons et se sont nourris principalement de macrophytes submergés. Malgré des recherches importantes examinant la sélectivité du broutage chez les poissons herbivores, les préférences alimentaires des petits poissons omnivores en matière de macrophytes sont mal comprises. Nous avons mené une expérience en mésocosme pour examiner les effets d'un petit poisson omnivore prolifique, Acheilognathus macropterus, sur le taux de croissance relatif (RGR) et la biomasse des macrophytes submergés (Ceratophyllum demersum, Myriophyllum spicatum, Vallisneria denseserrulata et Hydrilla verticillata). Nos résultats ont montré que la présence d'A. macropterus augmentait de manière significative les concentrations de nutriments (par exemple, l'azote total et le phosphore total). Le RGR de C. demersum en présence du poisson était significativement plus faible que celui des témoins, en présence d'autres espèces de macrophytes. En outre, la biomasse totale des quatre espèces de macrophytes dans les mésocosmes où se trouvent des poissons était nettement inférieure à celle du témoin en l'absence de poissons, ce qui suggère une consommation considérable de macrophytes par les poissons. En outre, le

\footnotetext{
*Corresponding author: jlyu@niglas.ac.cn
} 
pourcentage de biomasse de $V$. denserrulata et $H$. verticillata a été considérablement augmenté par la présence du poisson. Nos résultats suggèrent que $A$. macropterus peut augmenter les concentrations de nutriments par l'excrétion et réduire la biomasse et le RGR de certains macrophytes submergés, ce qui peut modifier la structure de la communauté de macrophytes par un broutage age sélectif.

Mots clés : Omnivorie / Ceratophyllum / bouvière / préférence alimentaire / herbivorie

\section{Introduction}

Submerged macrophytes are crucial in stabilizing shallow lake ecosystems through maintaining ecosystem functions, like nutrient cycling and biomass production (Scheffer et al., 1993; Jeppesen et al., 1998). Due to the role of these functions in maintenance of lake stability, recovery of submerged macrophytes has become an important consideration for restoration of shallow eutrophic lakes (Horppila and Nurminen, 2003; Hilt et al., 2010; Liu et al., 2018). However, natural recovery of macrophyte community after large scale restoration in lakes can take more than a decade (Hilt et al., 2010). Recently, biomanipulation of fish assemblages (removal of omni-benthivores and stocking of piscivores) and transplantation of submerged macrophytes has become a popular practice in restoration of subtropical and tropical shallow lakes in China (Liu et al., 2018; Yu et al., 2016b). In some lakes restored by using this practice, re-oligotrophic conditions were obtained and water clarity improved where external nutrient loading was well controlled (Yu et al., 2016b; Gao et al., 2017; Liu et al., 2018). However, despite stocking of piscivorous fish, the fish assemblage in some tropical lakes returned to be dominated by omnivores (Gao et al., 2014). Moreover, in a subtropical restored shallow lake, the return of the fish assemblage to small omnivore-dominance coincided with a large contribution of macrophyte to the diet of omnivores in Lake Wuli, China (Yu et al., 2016a).

Herbivorous fish (e.g. grass carp Ctenopharyngodon idella) have been known to reduce macrophyte biomass (Ṕipalová, 2002; Yu et al., 2016c), and shift macrophyte community structure by grazing selectively on preferred species (e.g. Vallisneria spinulosa and Ceratophyllum demersum) (Yu et al., 2016c). However, the effects of grazing by omnivorous fishes are less well known. To this end, Yu et al. (2016a) examined the diets of the dominant omnivorous fish in a subtropical shallow, macrophyte-dominated lake, and found that each of the four dominant omnivorous fish species (Pseudorasbora parva, Acheilognathus macropterus, Carassius carassius and Hemiculter leucisculus) fed mainly on submerged macrophytes. These findings are contrary to prior published results suggesting relatively low reliance on macrophytes by omnivorous fishes (Dorenbosch and Bakker, 2011).

Many studies have suggested omnivorous fish affect macrophytes indirectly by altering concentrations of nutrients and suspended solids (Drenner et al., 1998) which then modulate phytoplankton biomass and the light attenuation (Menezes et al., 2010), thereby affecting growth of submerged macrophytes (Gu et al., 2016). Studies investigating the effects of direct grazing by omnivorous fishes on macrophytes have focused on large body-size species such as common carp (Cyprinus carpio) (Lougheed and Chow-Fraser, 1998; Miller and Crowl, 2006) while neglecting the impacts of small omnivores like $A$. macropterus. However, small omnivores are commonly found among macrophytes (Ye et al., 2006), and macrophytes can be a large proportion of the diet of these fish (Yu et al., 2016a). To date, few studies have directly sought to investigate the grazing effects and feeding preferences of small omnivorous fish on macrophytes.

Bitterling fish A. macropterus (family Cyprinidae) is a smallbodied fish known to consume various foods including zooplankton, plant material, algae, and submerged macrophytes (Ye et al., 2006; Yu et al., 2016a; Usui et al., 2018). In addition to the wide range of foods acceptable to A. macropterus, there is evidence to suggest considerable $A$. macropterus diet plasticity depending on environmental conditions. For example, in a study of fish diets in reed belts of Lake Kitaura, Japan, A. macropterus was classified to an omnivorous group consuming diatoms, filamentous algae, and decomposing reeds (Usui et al., 2018). Whereas in macrophyte-dominated shallow Lake Wuli, China, both small- and large-sized A. macropterus fed mainly on submerged macrophytes (Yu et al., 2016a). Confoundingly, macrophytes consumed by fishes are not commonly identified into species in diet studies (Yu et al., 2016a), and, to date, macrophyte-species-level resolution of grazing selectivity of A. macropterus is not apparent.

Species-level resolution of grazing selectivity has been demonstrated in many herbivorous fish, like grass carp (C. idella; Yu et al., 2016c) and Wuchang bream (Megalobrama amblycephala) (Yin et al., 2019), despite the anatomical ability of these herbivores to consume most macrophytes. Unlike grass carp, small omnivorous fish, like A. macropterus, have small mouth-gape which may restrict their feeding to small-leaf macrophytes species. Thus, we hypothesized mouth gape restrictions will cause preferential macrophyte grazing in small omnivorous fishes. We predicted A. macropterus would preferentially graze on small-leaf macrophytes like Hydrilla verticillate, Ceratophyllum demersum, and Myriophyllum spicatum and less on large-leaf macrophytes like Vallisneria denseserrulata. Preferential grazing of $A$. macropterus would thereby (1) reduce the growth rate and biomass of small-leaf macrophytes and (2) facilitate the growth rate and biomass of large-leafed macrophytes. To test this hypothesis, we conducted mesocosm experiments to study the effects of A. macropterus on the growth and biomass of macrophytes. We included four species of macrophytes (small-leafed $H$. verticillata, C. demersum, $M$. spicatum, and large-leafed $V$. denseserrulata) in our study because these macrophytes are commonly used in restoration of shallow eutrophic lakes (Chen et al., 2009; Yu et al., 2016b; Gao et al., 2017; Liu et al., 2018).

\section{Materials and methods}

\subsection{Experimental design}

The mesocosm experiments were conducted in autumn 2019 at Eastern Lake Taihu Field Station, on the southeast 
Table 1. Size of submerged macrophytes and fish added to each treatment. Values are reported as mean \pm standard error.

\begin{tabular}{|c|c|c|c|c|c|}
\hline \multirow[t]{2}{*}{ Treatments } & \multicolumn{4}{|c|}{$\begin{array}{l}\text { Plant addition } \\
\left.\text { (g plant }^{-1}\right)\end{array}$} & \multirow{2}{*}{$\begin{array}{l}\begin{array}{l}\text { Fish addition } \\
\text { (cm } \text { ind. }^{-1} \text { ) }\end{array} \\
\begin{array}{l}\text { Acheilognathus } \\
\text { macropterus }\end{array}\end{array}$} \\
\hline & $\begin{array}{l}\text { Vallisneria } \\
\text { denseserrulata }\end{array}$ & $\begin{array}{l}\text { Hydrilla } \\
\text { verticillata }\end{array}$ & $\begin{array}{l}\text { Ceratophyllum } \\
\text { demersum }\end{array}$ & $\begin{array}{l}\text { Myriophyllum } \\
\text { spicatum }\end{array}$ & \\
\hline Fish-absent & $1.3 \pm 0.02$ & $0.4 \pm 0.02$ & $2.5 \pm 0.1$ & $2.2 \pm 0.05$ & \\
\hline Fish-present & $1.2 \pm 0.03$ & $0.4 \pm 0.02$ & $2.5 \pm 0.04$ & $2.1 \pm 0.07$ & $9.7 \pm 0.2$ \\
\hline
\end{tabular}

shore of Lake Taihu, China. First, approximately 300 L water were collected from a fishless pond at the field station and filtered through a plankton net (mesh size: $64 \mu \mathrm{m}$ ). After collection, water was stored in a high-density polyethylene (HDPE) tank (500 L). Next, eight plexiglass cylindermesocosms (inner diameter: $15 \mathrm{~cm}$, height: $30 \mathrm{~cm}$ ) were placed on a table and $4 \mathrm{~L}$ of water from the tank added to each mesocosm. Then, light intervals were set at $12 \mathrm{~h}$ light and $12 \mathrm{~h}$ dark by manipulating the lab LED light system consisted of seven lamp panels, each with three 15-watt LED lamps. Light intensity at the mesocosms' water surface was $9.4 \pm 0.6 \mu \mathrm{mol} \mathrm{m}^{-2} \mathrm{~s}^{-1}$ measured with a digital lux meter (ZDS-10w, Shanghai, China).

The eight mesocosms were divided into two treatments, fish-present and fish-absent, to provide four replicates of each treatment. One green-leaved shoot from each macrophyte species (Tab. 1) was added to each mesocosm. Each macrophyte was affixed to a small rope and with a rock fastened to the bottom of each rope. This design enabled each macrophyte to remain vertically suspended in the water column. One fish was added to each of the four fish-present mesocosms.

Fish and macrophytes used in this study were collected from Lake Taihu. After collection, macrophytes were washed with tap water to remove any attached material and weighed while wet (Tab.1). Collected fish were identified to species and total length recorded. Fish used in experiments had a mean total length of $9.7 \mathrm{~cm}$ (standard error $0.2 \mathrm{~cm}$, Tab. 1) and a mean wet weight of $8.7 \mathrm{~g}$ ind. $^{-1}$ (standard error $0.2 \mathrm{~g}$ ). All fish and macrophytes used in this study were cultured in tanks of filtered Lake Taihu water for 10 days prior to start the experiment. The experiment ran for 11 days and water temperature in each mesocosm kept steady between 15.1 and $15.9^{\circ} \mathrm{C}$ during this time by the lab air conditioning system.

\subsection{Sampling and data collection}

\subsubsection{Physio-chemical parameters}

The concentrations of total nitrogen (TN), total phosphorus (TP), total dissolved nitrogen (TDN), total dissolved phosphorus (TDP), ammonia $\left(\mathrm{NH}_{4}^{+}\right)$and soluble reactive phosphorus (SRP) were measured at the beginning and end of the experiment, according to Chinese Standard Methods for Monitoring Lake Eutrophication (Jin and Tu, 1990).

\subsubsection{Growth of macrophytes}

At the end of the experiment, each macrophyte species was re-weighed while wet. The relative growth rate (RGR) of each species of macrophytes in each mesocosm was calculated using the equation: RGR $\left(\mathrm{mg} \mathrm{g}^{-1} \mathrm{~d}^{-1}\right)=1000 \times \ln \left(W_{f} / W_{i}\right) /$ $W_{i} /$ days, where $W_{f}(\mathrm{~g})$ and $W_{i}(\mathrm{~g})$ were final and initial total macrophyte biomass in each mesocosm.

\subsection{Statistical analysis}

We used Student's $t$-tests to test differences in nutrient concentrations, RGR of each macrophyte species, and total biomass of the four macrophyte species between the fishabsent and fish-present treatments. Prior to analysis, if needed, data were $\log _{10} x$ transformed to meet the assumption of normality or homogeneity of variance. All comparisons were conducted using the statistical package SPSS, version 22.0 (IBM Corporation, Somers, NY, USA).

\section{Results}

\subsection{Nutrient concentrations}

At the end of our experiment, the concentrations of $\mathrm{TN}$, TDN, ammonia, and TP in the fish-present mesocosms were significantly higher than in the fish-absent mesocosms (Tab. 2; Fig. 1a-d). However, both TDP and SRP concentrations did not differ significantly between the fish-present and fish-absent treatments (Tab. 2; Fig. 1e,f).

\subsection{Growth of submerged macrophytes}

Relative growth rate (RGR) of $H$. verticillata and $V$. denseserrulata were positive in both treatments (Fig. 2a). However, RGR of $C$. demersum and $M$. spicatum were only positive in the absence of fish, while the RGR of $C$. demersum was significantly lower in the fish-present mesocosms than in the controls ( $t$-test, $t=4.664, p=0.003$; Tab. 2; Fig. 2a).

\subsection{Biomass of submerged macrophytes}

At the end of the experiment, the total biomass of the four species of macrophytes in the fish-present treatment was significantly lower than in the fish-absent treatment ( $t=2.854, p=0.029$; Tab. 2). However, the percentage biomass of $V$. denseserrulata $(t=3.807, p=0.009)$ and $H$. verticillate $(t=3.102, p=0.021)$ were significantly enhanced by the presence of bitterling (Tab. 2; Fig. 2b). 
Table 2. Students' $t$-test results of total nitrogen (TN), total dissolved nitrogen (TDN), ammonia $\left(\mathrm{NH}_{4}{ }^{+}\right)$, total phosphorus (TP), total dissolved phosphorus (TDP) and soluble reactive phosphorus (SRP), the relative growth rate (RGR) of submerged macrophytes, and percent biomass (\%) and total biomass of submerged macrophytes between the fish-absent and fish-present treatments. Statistical significance where $p<0.05$ is labelled in bold.

\begin{tabular}{|c|c|c|c|}
\hline \multirow[t]{2}{*}{ Comparisons } & \multirow[t]{2}{*}{ Variables/Species } & \multicolumn{2}{|c|}{ Statistical parameters } \\
\hline & & $t$ & $P$ \\
\hline \multirow{6}{*}{ Nutrients } & $\mathrm{TN}$ & 14.677 & $<\mathbf{0 . 0 0 0 1}$ \\
\hline & TDN & 15.670 & $<\mathbf{0 . 0 0 0 1}$ \\
\hline & $\mathrm{NH}_{4}^{+}$ & 11.459 & $<0.0001$ \\
\hline & $\mathrm{TP}$ & 4.592 & 0.004 \\
\hline & TDP & 1.546 & 0.173 \\
\hline & SRP & 2.179 & 0.072 \\
\hline \multirow{4}{*}{ RGR of macrophytes } & H. verticillata & 1.049 & 0.335 \\
\hline & V. denseserrulata & 2.404 & 0.053 \\
\hline & C. demersum & 4.664 & 0.003 \\
\hline & M. spicatum & 1.511 & 0.181 \\
\hline \multirow{4}{*}{ Percent biomass (\%) of each macrophyte species } & $\% H$. verticillata & 3.102 & 0.021 \\
\hline & $\% V$. denseserrulata & 3.807 & 0.009 \\
\hline & $\%$ C. demersum & 0.319 & 0.760 \\
\hline & $\%$ M. spicatum & 2.126 & 0.078 \\
\hline Total biomass of the plants & Total biomass & 2.854 & 0.029 \\
\hline
\end{tabular}
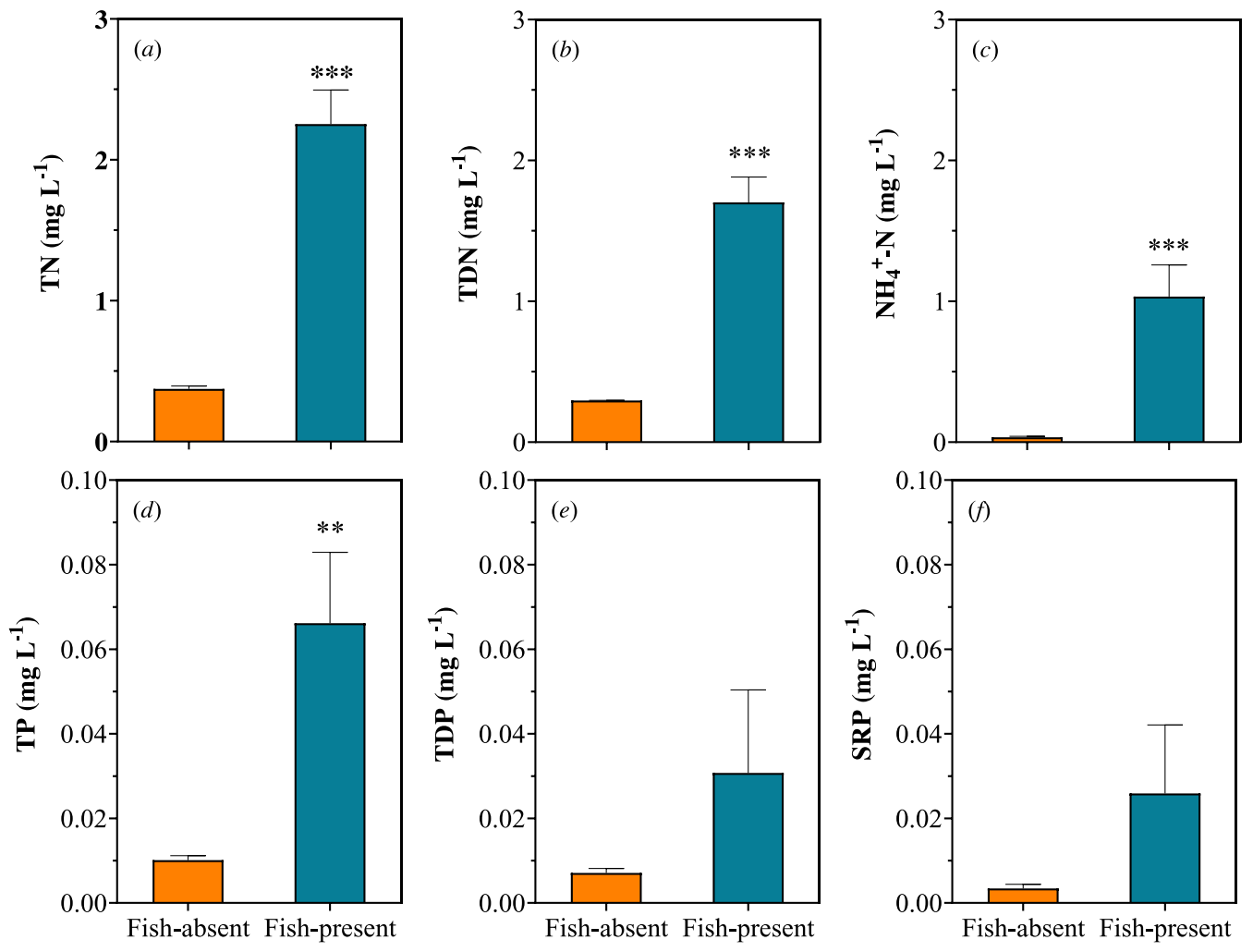

Fig. 1. Nutrient concentrations in treatments with absence and presence of fish A. macropterus, respectively. Error bars represent the standard error of mean (SEM). ${ }^{* *} P<0.01, * * * P<0.0001$. 

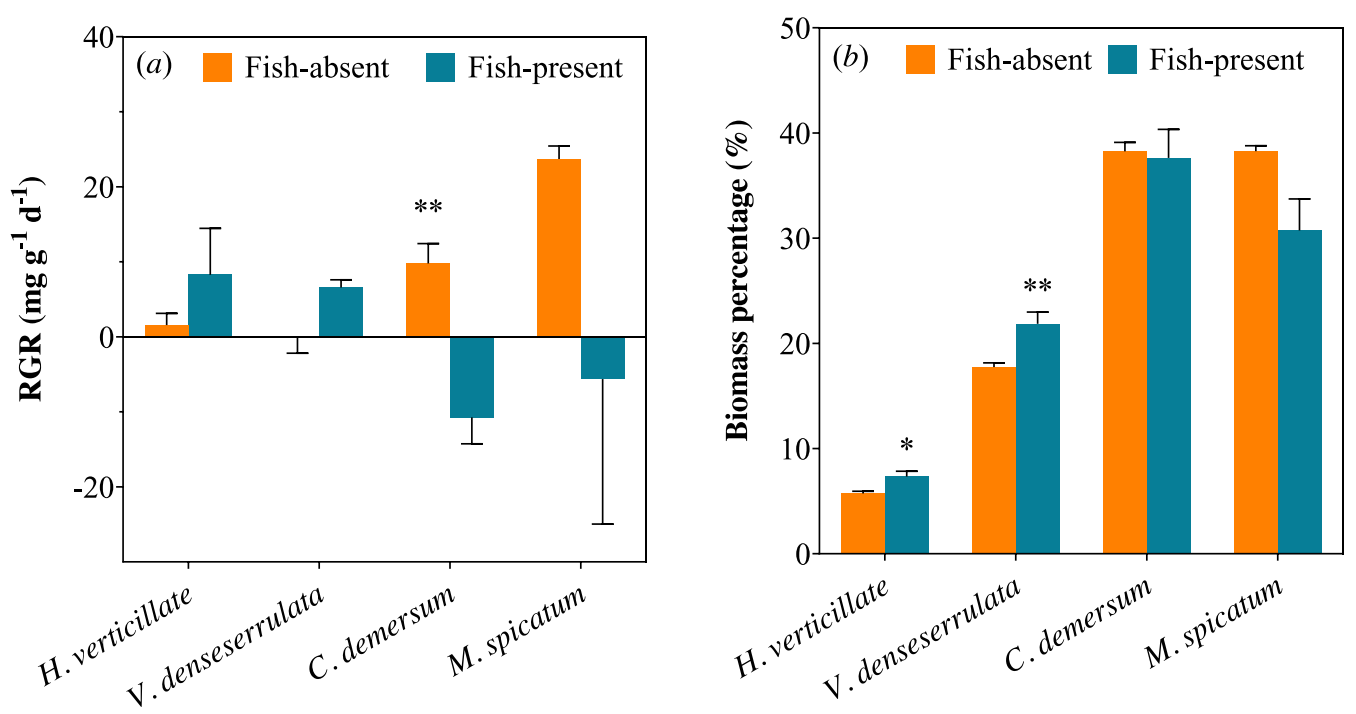

Fig. 2. The relative growth rate (RGR) of submerged macrophytes $(a)$ and biomass percentage of plants $(b)$ in treatments with absence and presence of fish A. macropterus, respectively. H. verticillate (small-leaf), V. denseserrulata (large-leaf), C. demersum (small-leaf), M. spicatum (small-leaf). Error bars represent the standard error of mean (SEM). ${ }^{*} P<0.05 ; * * P<0.01$.

\section{Discussion}

\subsection{Bitterling effects on nutrient concentrations}

Fish excretion being known to affect both nitrogen and phosphorous concentrations in the water column (Brabrand et al., 1990; Attayde and Hansson, 2001) and SRP being the main form of phosphorus excreted by fish (Vanni, 2002). However, concentrations of TDP and SRP did not differ significantly regardless of fish presence or absence in our experiments which is in consistence with Yu et al. (2020a). One plausible explanation for these findings is fish excretion alleviated phosphorous limitation in our mesocosms thereby enabling phosphorous uptake by macrophytes for biomass production. Such a mechanism would produce stable TDP and SRP concentrations even as other nutrient concentrations fluctuated based on fish presence or absence. This supposition would align with other studies showing fish excretion can significantly increase water column nutrient concentrations (Attayde and Hansson, 2001; Vanni et al., 2006) and primary production is phosphorous limited in some aquatic systems (Carpenter et al., 1998). Further testing would be needed to confirm this SRP-limitation inference in our experimental design but such an inference would be in line with literature on phosphorus-limitation of primary producers in aquatic ecosystems (Elser et al., 2007; Ren et al., 2019).

\subsection{Bitterling effects on submerged macrophytes}

It is generally accepted that macrophyte growth rates correlates with water nutrient concentrations (Denny, 1972; Best and Mantai, 1978). In our experiment, however, the growth rates of macrophytes in the fish-present treatment were not markedly enhanced by the increased nutrient concentration from fish excretion. On the contrary, RGR of $C$. demserum was considerably reduced, despite increased nutrient concentration in the presence of $A$. macropterus. We attribute this apparent contradiction mainly to selective grazing by $A$. macropterus. In a previous study, A. macropterus may consumed Hydrilla, Vallisneria, Ceratophyllum and Myriophyllum as their main food in a restored shallow lake (Yu et al., 2016a). However, relative contribution of each macrophyte species to the diet of A. macropterus was not evaluated (Yu et al., 2016a). Our results suggest that A. macropterus prefer to feed on $C$. demersum over other macrophyte species (Fig. 2a). Grazing selectivity in A. macropterus is not an unexpected result, though, because prey selection is reasonably common in freshwater fish. For example, stable isotope evidence showed that grass carp preferred $V$. spinulosa and C. demsersum to M. spicatum in Lake Qinhu, China (Yu et al., 2016c).

It has been suggested that high phenolic concentration may explain some grazing selectivity in freshwater fish (Dorenbosch and Bakker, 2011). For example, grass carp tend not to eat $M$. spicatum when other foods are available because M. spicatum has a high concentration of phenols (Dorenbosch and Bakker, 2011). Further, Smolders et al. (2000) showed that many macrophytes have relatively low phenolic concentrations and these levels are probably too low to deter herbivore feeding. Our experimental design does not account for phenolic concentration. Thus, it is unknown whether macrophyte phenolic concentration contributed to the grazing selectivity demonstrated by our results and future studies would be needed to parse these interactions.

To date, it has been established that herbivorous fish (e.g. grass carp) can significantly reduce macrophyte biomass (Pípalová, 2002; Dorenbosch and Bakker, 2012; Yu et al., 2016c), but the grazing effects of omnivorous fish on the biomass of macrophytes have remained debatable (Lake et al., 2002; Horppila and Nurminen, 2003; Dorenbosch and Bakker, 2012). Our results showed that omnivorous A. macropterus can cause significant reduction of macrophyte biomass. Specifically, in our experiment, A. macropterus preferred to eat smallleaf $C$. demsersum, and this is corroborated by findings from 
a field study by Yu et al. (2016c) which showed grazing fish preferentially consume $C$. demersum and $V$. spinulosa.

As our main purpose was to examine the direct effects of the small-size omnivore A. macropterus on the growth and biomass of four submerged macrophytes. Therefore, no alternative food was offered for A. macropterus in our study. This may induce a higher grazing pressure on the macrophytes species (e.g., C. demersum) than that in lakes with various food sources. For instance, in a field investigation, though submerged macrophytes were the important food for A. macropterus, however, zooplankton contributed about $30 \%$ to the diet of $A$. macropterus (Yu et al., 2016a).

\subsection{Implications for shallow lake restoration}

Bottom-up effects of submerged macrophytes on nutrients are considered to be an important mechanism for restoring water clarity in warm shallow lakes (Liu et al., 2018). However, restoration often shifts the fish assemblage in these lakes to favor small omnivores, like A. macropterus (Yu et al., 2016a). Our results demonstrate that A. macropterus can reduce the biomass and growth of macrophytes like $C$. demersum and M. spicatum through selective grazing. Our findings also show that RGR of other macrophytes, like $H$. verticillata and $V$. denseserrulata can remain positive in presence of $A$. macropterus. Thus, A. macropterus, and possibly other small-size omnivorous fishes, if abundant, may alter community structure, diversity, and reduce the biomass of macrophytes in lakes undergoing restoration. Moreover, A. macropterus excretion can significantly increase water column nutrient concentrations, thereby stimulate the phytoplankton growth (Yu et al., 2020b) which in turn indirectly affect the growth of submerged macrophytes via shading effects. Therefore, the biomass of small omnivorous fish, like A. macropterus in our study, should be monitored and controlled, if abundant, when restoring or managing of shallow lakes.

Acknowledgements. We thank Charles Wainright for language assistance and comments on an earlier draft. The paper was largely improved by suggestions from both anonymous reviewers and editor, we appreciate their time and inputs. This study was supported by the National Natural Science Foundation of China (41877415), National Key Research and Development Project (2017YFA0605201), and the NIGLAS 135 Project (NIGLAS2018GH01). JY was supported by the Chinese Academy of Sciences (CAS) Scholarship for a oneyear research visit at the Flathead Lake Biological Station, University of Montana, United States of America.

\section{References}

Attayde JL, Hansson L-A. 2001. The relative importance of fish predation and excretion effects on planktonic communities. Limnol Oceanogr 46: 1001-1012.

Best MD, Mantai KE. 1978. Growth of Myriophyllum: sediment or lake water as the source of nitrogen and phosphorus. Ecology 59: 1075-1080.

Brabrand Å, Faafeng BA, Moritz Nilssen JP. 1990. Relative importance of phosphorus supply to phytoplankton production: fish excretion versus external loading. Can J Fish Aquat Sci 47: 364-372.
Carpenter SR, Cole JJ, Kitchell JF, Pace ML. 1998. Impact of dissolved organic carbon, phosphorus, and grazing on phytoplankton biomass and production in experimental lakes. Limnol Oceanogr 43: 73-80.

Chen K-N, Bao C-H, Zhou W-P. 2009. Ecological restoration in eutrophic Lake Wuli: A large enclosure experiment. Ecol Eng 35: 1646-1655.

Denny P. 1972. Sites of nutrient absorption in aquatic macrophytes. J Ecol 60: 819-829.

Dorenbosch M, Bakker ES. 2011. Herbivory in omnivorous fishes: effect of plant secondary metabolites and prey stoichiometry. Freshw Biol 56: 1783-1797.

Dorenbosch M, Bakker ES. 2012. Effects of contrasting omnivorous fish on submerged macrophyte biomass in temperate lakes: a mesocosm experiment. Freshw Biol 57: 1360-1372.

Drenner RW, Gallo KL, Baca RM, Smith JD. 1998. Synergistic effects of nutrient loading and omnivorous fish on phytoplankton biomass. Can J Fish Aquat Sci 55: 2087-2096.

Elser JJ, Bracken MES, Cleland EE, Gruner DS, Harpole WS, Hillebrand H, Ngai JT, Seabloom EW, Shurin JB, Smith JE. 2007. Global analysis of nitrogen and phosphorus limitation of primary producers in freshwater, marine and terrestrial ecosystems. Ecol Lett 10: 1135-1142.

Gao H, Qian X, Wu H, Li H, Pan H, Han C. 2017. Combined effects of submerged macrophytes and aquatic animals on the restoration of a eutrophic water body - a case study of Gonghu Bay, Lake Taihu. Ecol Eng 102: 15-23.

Gao J, Liu Z, Jeppesen E. 2014. Fish community assemblages changed but biomass remained similar after lake restoration by biomanipulation in a Chinese tropical eutrophic lake. Hydrobiologia 724: 127-140.

Gu J, Jin H, He H, Ning X, Yu J, Tan B, Jeppesen E, Li K. 2016. Effects of small-sized crucian carp (Carassius carassius) on the growth of submerged macrophytes: implications for shallow lake restoration. Ecol Eng 95: 567-573.

Hilt S, Weyer KV de, Köhler A, Chorus I. 2010. Submerged macrophyte responses to reduced phosphorus concentrations in two peri-urban lakes. Restor Ecol 18: 452-461.

Horppila J, Nurminen L. 2003. Effects of submerged macrophytes on sediment resuspension and internal phosphorus loading in Lake Hiidenvesi (southern Finland). Water Res 37: 4468-4474.

Jeppesen E, Lauridsen TL, Kairesalo T, Perrow MR. 1998. Impact of submerged macrophytes on fish-zooplankton interactions in lakes. In Jeppesen E, Søndergaard M, Søndergaard M, Christoffersen K, eds. The Structuring Role of Submerged Macrophytes in Lakes. New York, NY: Springer New York, 91-114.

Jin X, Tu Q. 1990. The standard methods for observation and analysis in lake eutrophication. Beijing: Environmental Science.

Lake MD, Hicks BJ, Wells RDS, Dugdale TM. 2002. Consumption of submerged aquatic macrophytes by rudd (Scardinius erythrophthalmus L.) in New Zealand. Hydrobiologia 470: $13-22$.

Liu Z, Hu J, Zhong P, Zhang X, Ning J, Larsen SE, Chen D, Gao Y, He H, Jeppesen E. 2018. Successful restoration of a tropical shallow eutrophic lake: strong bottom-up but weak top-down effects recorded. Water Res 146: 88-97.

Lougheed VL, Chow-Fraser P. 1998. Factors that regulate the zooplankton community structure of a turbid, hypereutrophic Great Lakes wetland. Can J Fish Aquat Sci 55: 150-161.

Menezes RF, Attayde JL, Rivera, Vasconcelos F. 2010. Effects of omnivorous filter-feeding fish and nutrient enrichment on the 
plankton community and water transparency of a tropical reservoir. Freshw Biol 55: 767-779.

Miller SA, Crowl TA. 2006. Effects of common carp (Cyprinus carpio ) on macrophytes and invertebrate communities in a shallow lake. Freshw Biol 51: 85-94.

P'palová I. 2002. Initial impact of low stocking density of grass carp on aquatic macrophytes. Aquat Bot 73: 9-18.

Ren Z, Niu D, Ma P, Wang Y, Fu H, Elser JJ. 2019. Cascading influences of grassland degradation on nutrient limitation in a high mountain lake and its inflow streams. Ecology 100: e02755.

Scheffer M, Hosper SH, Meijer M-L, Moss B, Jeppesen E. 1993. Alternative equilibria in shallow lakes. Trends Ecol Evol 8: 275-279.

Smolders AJP, Vergeer LHT, Velde GVD, Roelofs JGM. 2000. Phenolic contents of submerged, emergent and floating leaves of aquatic and semi-aquatic macrophyte species: why do they differ? Oikos 91: 307-310.

Usui S, Kanou K, Sano M. 2018. Food habits of fishes in a freshwater reed belt in Lake Kitaura, eastern Japan, in summer. Fisheries Sci 84: 469-476.

Vanni MJ. 2002. Nutrient cycling by animals in freshwater ecosystems. Annu Rev Ecol Syst 33: 341-370.

Vanni MJ, Bowling AM, Dickman EM, Hale RS, Higgins KA, Horgan MJ, Knoll LB, Renwick WH, Stein RA. 2006. Nutrient cycling by fish supports relatively more primary production as lake productivity increases. Ecology 87: 1696-1709.

Ye S, Li Z, Lek-Ang S, Feng G, Lek S, Cao W. 2006. Community structure of small fishes in a shallow macrophytic lake (Niushan Lake) along the middle reach of the Yangtze River, China. Aquat Living Resour 19: 349-359.
Yin C, Wang Z, Zhao Y, Gao Y, Zhen W, He X, Yin C, Guan B. 2019. Megalobrama amblycephala grazes preferentially on Hydrilla verticillata but makes more efficient use of Vallisneria denseserrulata: implications for biological control of submerged macrophytes. Knowl Manag Aquat Ecosyst 420: 30.

Yu J, Liu Z, He H, Zhen W, Guan B, Chen F, Li K, Zhong P, Teixeira-de Mello F, Jeppesen E. 2016a. Submerged macrophytes facilitate dominance of omnivorous fish in a subtropical shallow lake: implications for lake restoration. Hydrobiologia 775: 97-107.

Yu J, Liu Z, Li K, Chen F, Guan B, Hu Y, Zhong P, Tang Y, Zhao X, He H, Zeng H, Jeppesen E. 2016b. Restoration of shallow lakes in subtropical and tropical China: response of nutrients and water clarity to biomanipulation by fish removal and submerged plant transplantation. Water 8: 438.

Yu J, Xia M, Kong M, He H, Guan B, Liu Z, Jeppesen E. 2020a. A small omnivorous bitterling fish (Acheilognathus macropterus) facilitates dominance of cyanobacteria, rotifers and Limnodrilus in an outdoor mesocosm experiment. Environ Sci Pollut Res doi: 10.1007/s11356-020-08774-5.

Yu J, Xia M, Zhen W, Shen R, He H, Guan B, Elser JJ, Liu Z. 2020b. Density-dependent effects of omnivorous bitterling (Acheilognathus macropterus) on nutrient and plankton communities: implications for lake management and restoration. Hydrobiologia. doi: 10.1007/s10750-020-04335-6.

Yu J, Zhen W, Guan B, Zhong P, Jeppesen E, Liu Z. 2016c. Dominance of Myriophyllum spicatum in submerged macrophyte communities associated with grass carp. Knowl Manag Aquat Ecosyst 417: 24 .

Cite this article as: Yu J, Xia M, Zhen W, He H, Shen R, Guan B, Liu Z. 2020. A small omnivore fish (Acheilognathus macropterus) reduces both growth and biomass of submerged macrophytes: implications for shallow lake restoration. Knowl. Manag. Aquat. Ecosyst., $421,34$. 